\title{
Implementasi Tenaga Matahari 60 Wp Untuk Fasilitas Umum Area Parkir Di Perum Villa Mutiara Serpong, Tangerang Selatan, Banten
}

\author{
Muchamad Nur Qosim $^{1}$; Isworo Pujotomo ${ }^{2}$; Aas Wasri Hasanah ${ }^{3}$; Rinna Hariyati ${ }^{4}$ \\ 1,2,3,4 Fakultas Ketenagalistrikan dan Energi Terbarukan, Institut Teknologi PLN \\ ${ }^{1}$ m.qosim@itpln.ac.id
}

\begin{abstract}
The existence of street lighting and / or public facilities is very important for the convenience of residents, especially in the car park at night. However, not all of them have installed lighting as in the land area, block B / C, stage 1, Villa Mutiara Serpong, Pondok Jagung, South Tangerang. This area is a land of public facilities whose area is still ground, and most of them have not installed lights to illuminate the entire area, because car parks also need lighting that is important enough to monitor unwanted things, therefore it is necessary to install the lighting of these public facilities and the road inside. this is in the form of solar powered lamps as an effective alternative for solutions in lighting and reducing the cost of using electricity from PLN. Solar lights are installed at strategic points, namely in areas with little lighting. The lamp used is a 60-90 watt power lamp for better lighting. In addition to street lighting and public facilities, an economic analysis is also carried out in this activity by comparing the total costs required between incandescent lighting and solar power.

Where it is found that the nominal difference in rupiah is Rp.2,607,455, which is more efficient than incandescent PJU, and solar lamps are not affected by TDL (basic electricity cost).
\end{abstract}

Keywords: parking area, Public Facilities, Lights, Solar Energy

\begin{abstract}
ABSTRAK
Keberadaan penerangan jalan dan atau fasilitas umum adalah salah satu hal yang sangat penting demi kenyamanan warga khususnya di area parkir mobil malam hari. Tetapi, tidak semuanya telah terpasang penerangan seperti halnya di area lapangan tanah, blok B/C tahap 1, Villa Mutiara Serpong, Pondok Jagung, Tangerang Selatan. Area ini merupakan lahan Fasum yang areanya masih tanah, dan sebagian besar belum terpasang lampu untuk penerangan seluruh areanya, karena parkir mobil juga membutuhkan pencahayaan yang cukup penting untuk memantau hal yang tidak diinginkan, oleh karena itu diperlukan pemasangan penerangan fasilitas umum tersebut dan jalan dalam hal ini berupa lampu tenaga surya sebagai alternatif efektif untuk solusi dalam penerangan dan pengurangan biaya pemakaian energi listrik dari PLN. Lampu tenaga surya di pasang di titik strategis yaitu di area yang sedikit pencahayaannya. Lampu yang digunakan adalah lampu daya 60-90 watt guna lebih terang lebih bagus. Selain untuk penerangan jalan dan fasilitas umum, analisis ekonomi juga dilakukan pada kegiatan ini dengan cara membandingkan total biaya yang diperlukan antara penerangan lampu pijar dengan tenaga surya.

Dimana didapat selisih nominal dalam rupiah Rp 2.607.455 lebih efisien dari PJU lampu pijar, dan lampu tenaga surya tidak dipengaruhi oleh TDL (tarif dasar listrik).
\end{abstract}

Kata Kunci: Parkiran, Fasilitas Umum, Lampu, Tenaga Surya 


\section{PENDAHULUAN}

Pada kehidupan sekarang ini bahwa teknologi semakin cepat berkembang, kebutuhan akan listrik pun juga semakin banyak, PLTS sudah menjadi barang umum di masyarakat, namun barang dan bentukkannya masih dirasa mahal karna tidak dan belum ada di setiap daerah ada penjualnya masih kategori produk langka dan mahal. Oleh sebab itu situasi dan kondisi di tempat atau area pengabdian ini di jalankan merupakan area umum, dimana penerangan cahaya malam terlihat kurang atau masih gelap.

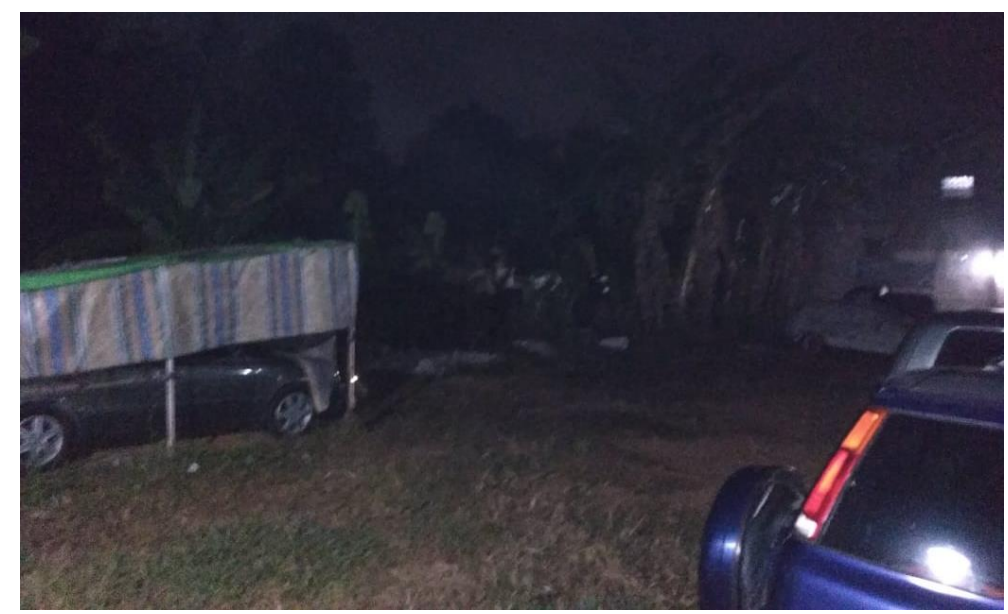

Gambar 1. Kondisi yang akan di pasang PLTS

Dari segi sosial dimana kondisi area parkir dihuni kendaraan dari berbagai RT, tetapi posisi di wilayah RT 03. Dengan lebih terang akan memungkinkan kenyamanan lebih terasa, karna apabila malam akan terang, apabila ada hewan melata atau sejenisnya akan lebih kelihatan, dan akan semakin mempererat antar sesama pengguna untuk saling merawat dari area dan kebutuhan area, yang tidak lain yaitu PLTS nya.

Dengan sedikit penambahan penerangan memungkinkan akan membangkitkan semangat kebersamaan saling menjaga dalam keamanan dan penglihatan yang lebih terang akan memudahkan diawasi apabila akan ada yang berbuat tidak baik, atau orang luar yang mencurigakan.

Area lahan parkir emang dari kenyataan lahan yang kurang jelas untuk statusnya, namun sudah belasan tahun kondisinya seperti itu. Untuk pemanfaatan parkir kendaraan tidak masalah, tetapi tidak bisa dimanfaatkan lebih; seperti pengecoran lahan, pemasangan atap, namun apabila dipasang PLTS yang fleksible sangat membantu guna selain nambah terang dan lebih terasa aman.

Dengan pihak mitra sangat suport apabila akan dipasang penerangan lampu dengan tenaga matahari atau solar cell (PLTS).

\section{METODE}

\subsection{Sifat dan Bentuk Kegiatan}

Implementasi Solar cell (PLTS) dalam satu sesi diharapkan diikuti oleh 20 - 30 orang peserta. Kegiatan ini dapat dilaksanakan dalam jangka waktu sekurang-kurangnya 8 (delapan) hari kerja dan berjangka dalam 1 tahun.

Langkah 1: Peserta diberikan contoh penerapan dan Implementasi PLTS dan tentang pengetahuan ilmu PLTS dasar dan manfaat energi matahari.

Langkah 2: Peserta diberikan pemahaman tentang apakah itu energi solar cell (PLTS). 
Langkah 3: Setelah peserta diberikan teori-teori tersebut, kemudian peserta akan diberikan contoh cara instalasi PLTS dan penanganan dari, serta bagaimanakah perawatan dan pemeliharaan dari pemakaian PLTS yang baik.

Langkah 4: Peserta diharapkan dapat melanjutkan dan menyebarluaskan keilmuan tentang dasar PLTS itu.

\subsection{Langkah Evaluasi}

Bentuk dari evaluasi akan di monitor setiap harinya yang akan di lakukkan oleh pihak mitra, serta akan diberikan form untuk isi hasil kinerja PLTS nya. Dari hasil sederhana harian akan di ringkas menjadi mingguan, bulanan dan akhirnya dalam 1 tahun kedepan apakah PLTS itu sangat bermanfaat atau ada kendala.

Adapun indikator keberhasilan:

1. Masyarakat sekitar yang telah dibrifing dan di beri pengetahuan tentang PLTS, pemasangan dan kegunaannya akan lebih paham tentang teknologi dari PLTS.

2. Dari awal pengenalan, pendahuluan dengan pihak mitra setempat sangat antusias dan semangat untuk menjadikan daerahnya sebagai area implementasi pengabdianya.

Untuk kemampuan dalam maintenance nya.

1. Masyarakat akan dibekali dari informasi awal apa itu PLTS.

2. Dengan implementasi atau percontohan secara langsung masyarakatnya akan lebih memahami secara praktik dan kinerjanya serta perawatanya.

Ada juga kontak person mitra guna saling komunikasi setiap ada keluhan atau kendala, maka dari itu sistem dalam pengamatan kedepan dilakukan secara manual. Karna masih menggunakan alat PLTS yang sederhana.

\subsection{Diagram Alir Kegiatan}

Diagram alir kegiatan dapat dilihat pada Gambar 2 berikut ini.

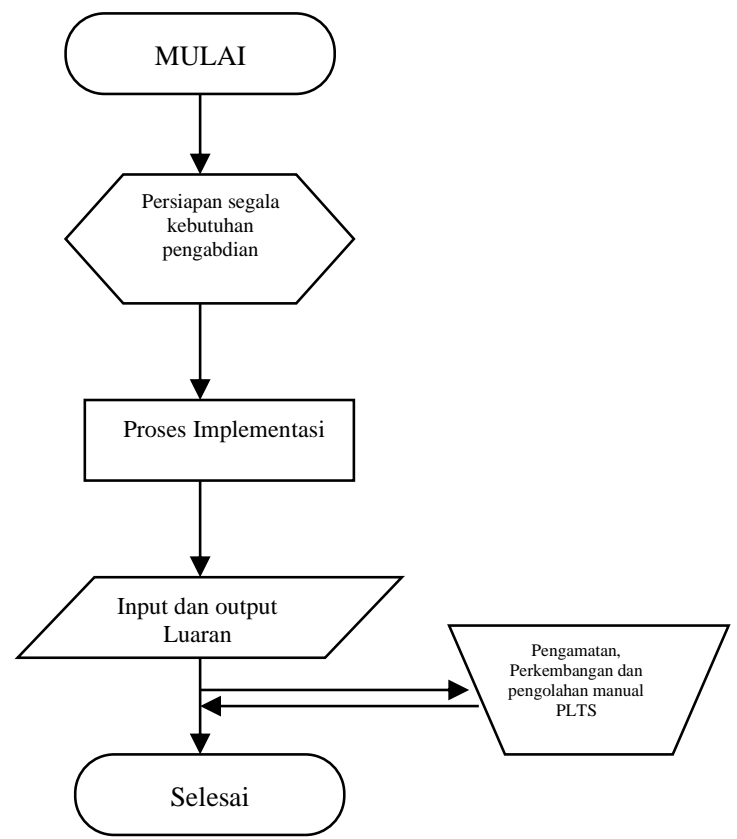

Gambar 2. Diagram Alir Kegiatan Pengabdian Kepada Masyarakat 


\section{HASIL DAN PEMBAHASAN}

Pada kegiatan pengabdian kepada masyarakat ini sebelum dilaksanakannya sosialisasi dan pelatihan, terlebih dahulu dilakukan survey lokasi yang di jadikan tempat pelaksanaan pengabdian kepada masyrakat ini, kemudian kami bersilahturahmi kepada para tokoh masyarakat atau pengampu yang ada di lingkungan setempat guna mendiskusikan tentang topic program yang akan dilaksanakan dan untuk mendapatkan ijin dan dukungan berupa penyediaan fasilitas tempat untuk dilakukannya sosialisasi dan pelatihan tentang PLTS ini.

Dimana pelaksanaan pengabdian kepada masayarakat ini akan dilakukan di lapangan tanah area fasilitas umum tempat parkir mobil, perum Villa Mutiara Serpong Tahap 1, Pondok Jagung, Serpong Utara, Tangerang Selatan dimana penerapan dari PLTS ini adalah berupa lampu penerangan di sekitaran area parkir.

\subsection{Kegiatan yang dilakukan}

Dalam sosialisasi itu masyarakat cukup antusias dalam mengulik dan penasaran dalam teknologinya dimana mereka banyak yang belum mengenal dan mengerti kenapa bisa sinar matahari itu bisa menghasilkan energi listrik. Nah disitulah peran besar kita sebagai dosen maupun perantara dalam dunia teknologi ini sangat dibutuhkan dan membantu masyarakat sekitar.

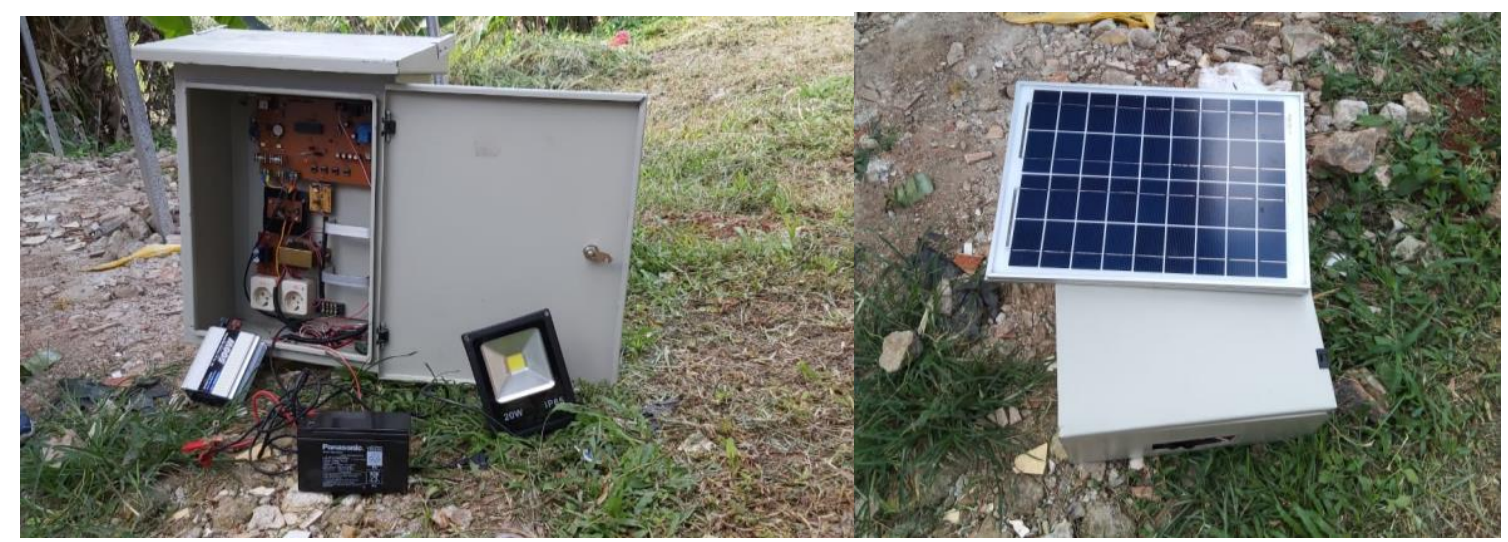

Gambar 3. Komponen dan bagian dari PLTS

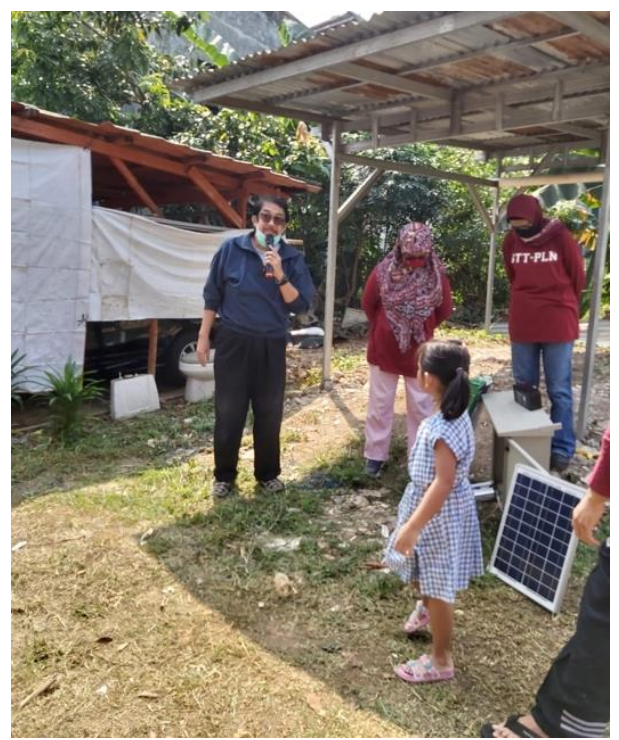

Gambar 4. Penjelasan tentang PLTS 
Untuk penjelasan itu setiap bahasan apa yang kita sampaikan boleh dengan langsung ditanyakan apa yang menjadi pertanyaan dan penasaran dari masyarakat. Karena hal itu untuk langsung lebih cepat dan mendalami sistemnya. Dalam konsep pemaparan dan sosialisasinya itu kami menggunakan metode pendekatan yang santai dan bersahaja (tidak formil dalam ruangan / aula) namun lagsung di area yang di pasang implementasinya PLTS nya.

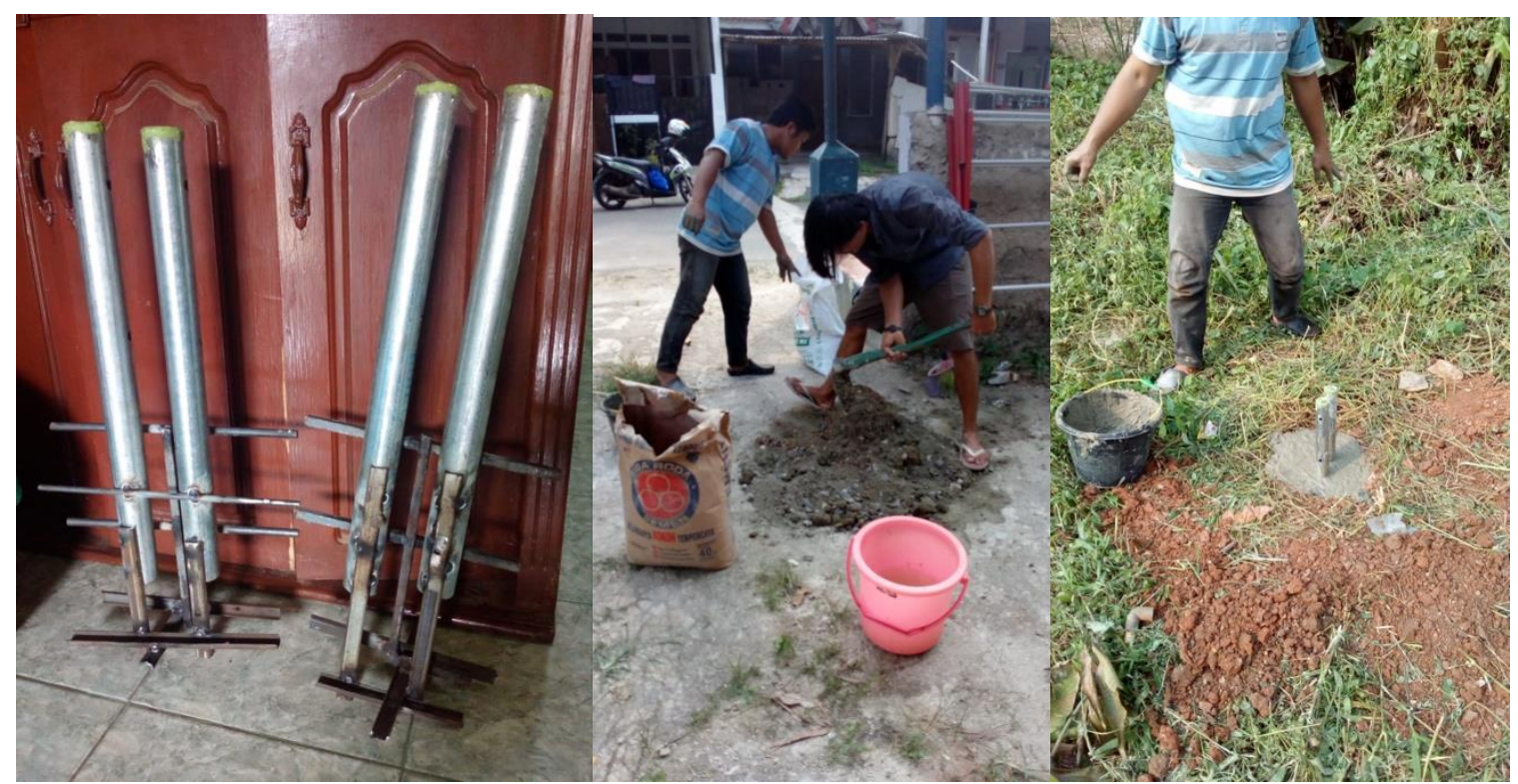

Gambar 5. Pemasangan Pondasi untuk Tiang Lampu PLTS

Setalah pemasangan pondasi tidak langsung serta merta dalam satu hari itu di pasang tiang penyangga PLTS nya, namun minimal di tunggu beberapa hari biar kuat dan kokoh bener bener kering untuk semen dan pondasi bawahnya.

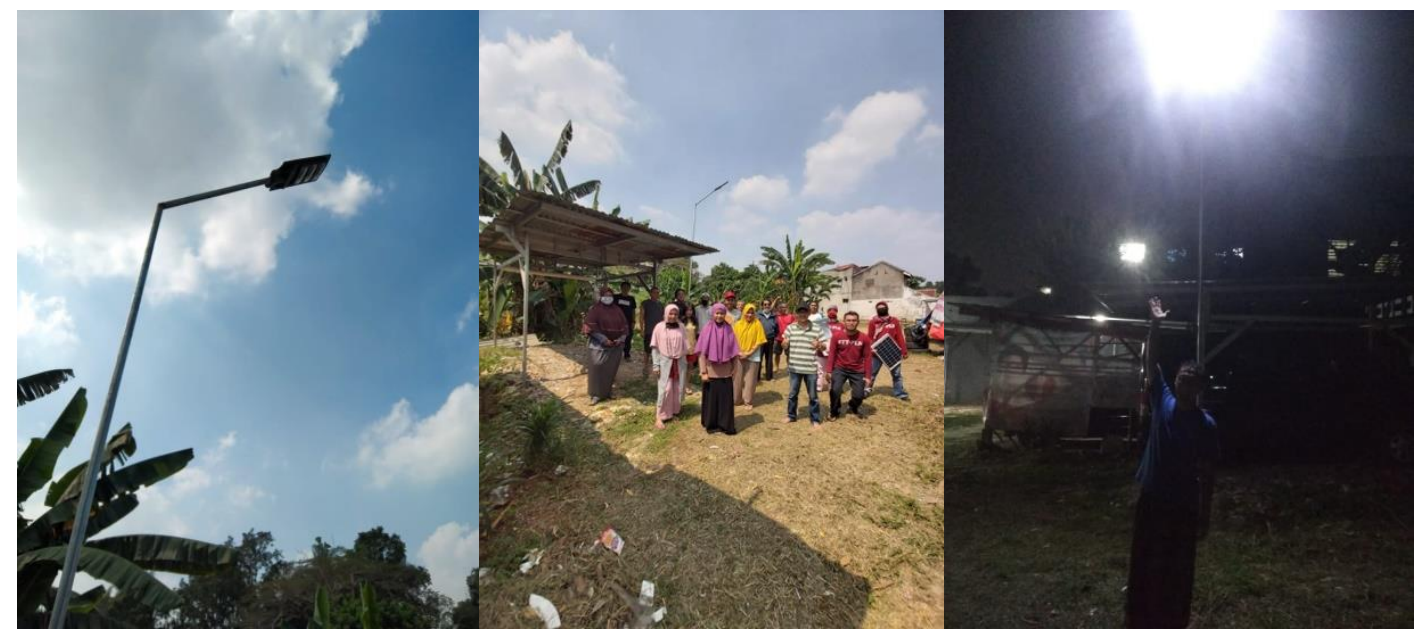

Gambar 6. Hasil memasang PLTS bersama warga sekitar

Hasil itu memberikan bukti nyata bahwa energy matahari bisa dipakai untuk menhasilkan listrik yang akan dipakai untuk penerangan, pencahayaan area lahan parkir yang masih gelap. Hasil itu sampai sekarang masih di pantau ternyata sangat efektip itu terbukti bahwa bisa menyala dari jam 18.00 sampai 05.00 WIB itu di buktikan setiap hari oleh penduduk sekitar yang melewati dan 
melihat hasil dari pemasangan PLTS itu. Dan masyarakat sekitar sangat senang dan mengerti besar sekali energy matahari kita ini selama ini.

\subsection{Analisis Manfaat Ekonomi dari Lampu Tenaga Surya yang Dipasang}

Analisis keekonomisan pada lampu tenaga surya yang terpasang dilakukan untuk melihat manfaat dari sisi ekonomi dibandingkan dengan penggunaan lampu pijar untuk PJU. Lampu yang terpasang merupakan lampu pijar karena menurut warga lampu pijar lebih murah daripada lampu LED atau TL. Pada poin ini, akan dianalisis perbandingan dari sisi ekonomi terhadap PJU lampu surya dengan PJU lampu pijar untuk 1 titik lampu selama kurun 5 tahun

Pada tabel 1, dianalisis harga total yang harus dikeluarkan untuk pemakaian PJU lampu pijar, dengan asumsi lampu pijar memerlukan penggantian pada tahun ke 5 dengan harga lampu tetap. Karena lampu PJU memperoleh pasokan listrik dari rumah warga, maka biaya listrik yang diperlukan menyesuaikan Tarif Dasar Listrik untuk rumah tangga tahun 2020 yaitu sebesar Rp 1.467 dengan asumsi tidak ada kenaikan TDL selama 5 tahun ke depan. Jika lampu menyala selama 12 jam, maka kebutuhan listrik perhari adalah:

Lampu pijar $=90$ watt $\times 12 \mathrm{jam}=1080 \mathrm{Wh}=1,080 \mathrm{KWh}(2 \mathrm{lampu})=2,160 \mathrm{KWh}$

Sedangkan selama 1 tahun, kebutuhan energi listrik untuk menghidupkan 1 lampu PJU adalah:

Wlampu pijar setahun $=2,160 \mathrm{KWh} \times 365$ hari $=788,4 \mathrm{KWh}$

Biaya listrik yang dikeluarkan selama 1 tahun adalah:

Biaya listrik setahun $=788,4 \mathrm{KWh} \times \mathrm{Rp} 1467=\mathrm{Rp} .1 .156 .582,8(2 \mathrm{lampu})$

Tabel 1. Analisis Biaya Penggunaan PJU Lampu Pijar

\begin{tabular}{|l|c|c|c|c|c|}
\hline \multicolumn{1}{|c|}{ Pengeluaran } & $\begin{array}{c}\text { Tahun ke-1 } \\
(\mathbf{R p})\end{array}$ & $\begin{array}{c}\text { Tahun ke-2 } \\
(\mathbf{R p})\end{array}$ & $\begin{array}{c}\text { Tahun ke-3 } \\
(\mathbf{R p})\end{array}$ & $\begin{array}{c}\text { Tahun ke- } \\
\mathbf{4} \\
(\mathbf{R p})\end{array}$ & $\begin{array}{c}\text { Tahun ke- } \\
\mathbf{5} \\
(\mathbf{R p})\end{array}$ \\
\hline $\begin{array}{l}\text { Lampu pijar 90 } \\
\text { Watt }\end{array}$ & $100.000,00$ & 0 & 0 & 0 & 0 \\
\hline Tiang besi & $1.000 .000,00$ & 0 & 0 & 0 & 0 \\
\hline Kap lampu & $30.000,00$ & 0 & 0 & 0 & 0 \\
\hline $\begin{array}{l}\text { Kabel AWG22x2 } \\
8 \text { meter }\end{array}$ & $50.000,00$ & 0 & 0 & 0 & 0 \\
\hline $\begin{array}{l}\text { Biaya listrik 1 } \\
\text { tahun }\end{array}$ & $578.291,00$ & $578.291,00$ & $578.291,00$ & $578.291,00$ & $578.291,00$ \\
\hline Total (pertahun) & $\mathbf{1 . 7 5 8 . 2 9 1 , 0 0}$ & $\mathbf{5 7 8 . 2 9 1 , 0 0}$ & $\mathbf{5 7 8 . 2 9 1 , 0 0}$ & $\mathbf{5 7 8 . 2 9 1 , 0 0}$ & $\mathbf{5 7 8 . 2 9 1 , 0 0}$ \\
\hline $\begin{array}{l}\text { TOTAL BIAYA } \\
\text { (5 tahun) }\end{array}$ & \multicolumn{5}{|r|}{$\mathbf{R p} \mathbf{4 . 1 0 7 . 4 5 5}$} \\
\hline
\end{tabular}

Pada tabel 1 dianalisis harga total yang harus dikeluarkan untuk pemakaian PJU lampu tenaga surya. Berdasarkan data sheet lampu, lampu PJU LED tenaga surya dapat digunakan selama 50.000 jam $=5,7$ tahun sebelum akhirnya lampu akan rusak. Sehingga, tidak diperlukan biaya penggantian lampu tenaga surya jika analisis yang dilakukan selama jangka waktu 5 tahun. Agar penyinaran PJU optimal, maka setiap tiang lampu terpasang 1 buah lampu tenaga surya. 
Tabel 2. Analisis Biaya Penggunaan PJU Lampu Tenaga Surya

\begin{tabular}{|l|c|c|c|c|c|}
\hline \multicolumn{1}{|c|}{ Pengeluaran } & $\begin{array}{c}\text { Tahun ke-1 } \\
(\mathbf{R p})\end{array}$ & $\begin{array}{c}\text { Tahun ke- } \\
\mathbf{2} \\
(\mathbf{R p})\end{array}$ & $\begin{array}{c}\text { Tahun ke- } \\
\mathbf{3} \\
(\mathbf{R p})\end{array}$ & $\begin{array}{c}\text { Tahun ke- } \\
\mathbf{4} \\
(\mathbf{R p})\end{array}$ & $\begin{array}{c}\text { Tahun ke- } \\
\mathbf{5} \\
(\mathbf{R p})\end{array}$ \\
\hline Lampu PLTS 90W & $500.000,00$ & 0 & 0 & 0 & 0 \\
\hline Tiang besi & $1.000 .000,00$ & 0 & 0 & 0 & 0 \\
\hline \hline Total (pertahun) & $\mathbf{1 . 5 0 0 . 0 0 0 , 0 0}$ & $\mathbf{0}$ & $\mathbf{0}$ & $\mathbf{0}$ & $\mathbf{0}$ \\
\hline $\begin{array}{c}\text { TOTAL BIAYA }(5 \\
\text { tahun) }\end{array}$ & \multicolumn{5}{|c|}{$\mathbf{R p ~ 1 . 5 0 0 . 0 0 0 , 0 0}$} \\
\hline
\end{tabular}

Berdasarkan hasil analisis pada tabel 1 dan 2, diperoleh perbedaan total biaya yang besar untuk pengoperasian kedua PJU selama 5 tahun. Untuk pengoperasian PJU lampu pijar selama 5 tahun, diperlukan biaya sebesar Rp 4.107.455. Sedangkan PJU lampu surya hanya memerlukan biaya Rp 1.500.000,-. Walaupun harga lampu PJU tenaga surya lebih mahal, tetapi untuk penggunaan jangka panjang, PJU lampu tenaga surya jauh lebih ekonomis dibandingkan PJU lampu pijar, dengan selisih biayanya adalah sebesar Rp 2.607.455 untuk jangka waktu 5 tahun.

\section{KESIMPULAN}

Kegiatan Program Kemitraan Masyarakat (PKM) mengenai Pemanfaatan Energi Surya untuk Penerangan area parkir fasilitas umum di perumahan Villa Mutiara Serpong Blok C/B, lapangan tanah, Pondok Jagung, Tangerang Selatan telah berhasil dilaksanakan pada bulan juli-agustus 2020. Kegiatan tersebut berupa pemasangan lampu dengan memanfaatkan tenaga surya. Lampu yang digunakan adalah lampu merk HILIOS SL-90 W (2 buah). Lampu juga memiliki sistem penyalaan otomatis dengan mendeteksi cahaya sekitar dan baterai tertanam sebesar 2000 mAh. Sebelum lampu tersebut dipasang, tim PKM melakukan survei lapangan untuk menentukan titik-titik pemasangan lampu. Diperoleh 2 titik pemasangan lampu yang strategis yaitu dibagian pojok lahan yang dimana tidak ada penerangan, selain kondisi masih lahan kosong (kebun liar)

Pemasangan lampu telah berhasil dilakukan. Lampu dapat beroperasi dengan baik pada malam hari. Analisis kinerja lampu tenaga surya juga ditinjau dari segi ekonomi dengan cara membandingkan total pengeluaran yang diperlukan untuk lampu PJU tenaga surya dan PJU yang menggunakan lampu pijar dengan sumber listrik dari rumah warga. Berdasarkan hasil perhitungan, pengoperasian PJU lampu pijar selama 5 tahun, memerlukan biaya sebesar Rp 4.107.455,-Sedangkan PJU lampu surya hanya memerlukan biaya Rp 1.500.000,-. Sehingga lampu tenaga surya jauh lebih ekonomis dibandingkan PJU lampu pijar, dengan selisih biayanya sebesar Rp 2.607.455,- untuk pemakaian jangka waktu 5 tahun. Sementara usia hidup nyala dari lampu PJU tenaga surya bisa mencapai 5,7 tahun, sehingga bila di analisis untuk ke ekonomisan dari lampu penerangan tenaga surya dan dibandingkan dengan biaya lampu pijar akan sangat terlihat perbedaannya.

\section{SARAN}

Apabila diterapkan di pelosok yang belum dapat listrik akan lebih berguna lagi, karena keterbatasan finansial dan jarak dimana jarak terjauh dengan kondisi relief saat ini dari IT-PLN kemungkinan besar masyrakatnya sudah bisa menikmati listrik, yang membedakanya hanya sumbernya dan teknologinya. 


\section{UCAPAN TERIMA KASIH}

Penulis mengucapkan terima kasih kepada Institut Teknologi PLN Jakarta dan LPPM atas kesempatan kepada tim PKM dan dukungan baik moril maupun materiil serta pendanaan sehingga kegiatan PKM dapat terlaksana dengan baik.

\section{DAFTAR PUSTAKA}

[1] Bachtiar, M. (2006). Prosedur Perencanaan Sistem Pembankit Listrik Tenaga Surya Untuk Perumahan (Solar Home System).

[2] Jurnal SMARTek, Vol. 4, No.3, Solarex, 1996, Discover the Newest Work Power, Frederick Court, Maryland, USA.

[3] Manan, Saiful. (2012) Energi Matahari, Sumber Energi Alternatif yang Effisiean, Handal dan Ramah Lingkungan di Indonesia. Jakarta, Indonesia.

[4] Panel Surya. (2017). Pembangkit Listrik Tenaga Surya (PLTS), panelsurya.com,

[5] S.G., Ramadhan; Ch. Rangkuti. (2016). Perencanaan Pembangkit Listrik Tenaga Surya Di Atap Gedung Harry Hartanto Universitas Trisakti. Jakarta, Indonesia 